\title{
Physicochemical and Antioxidant Properties of Cymbopogon citratus Essential Oil
}

\author{
María del Carmen Vázquez-Briones ${ }^{1}$, Luis Ricardo Hernández ${ }^{2}$ \& José Ángel Guerrero-Beltrán ${ }^{1}$ \\ ${ }^{1}$ Departamento de Ingeniería Química, Alimentos y Ambiental, Universidad de las Américas Puebla, Cholula, \\ Puebla, México \\ ${ }^{2}$ Departamento de Ciencias Químico Biológicas, Universidad de las Américas Puebla, Cholula, Puebla, México \\ Correspondence: José Ángel Guerrero-Beltrán, Departamento de Ingeniería Química, Alimentos y Ambiental, \\ Universidad de las Américas Puebla, Cholula, Puebla 72810, México. Tel: 52-222-229-2126. E-mail: \\ angel.guerrero@udlap.mx; joseangel150@hotmail.com
}

Received: December 17, 2014 Accepted: February 24, 2015 Online Published: February 26, 2015

doi:10.5539/jfr.v4n3p36

URL: http://dx.doi.org/10.5539/jfr.v4n3p36

\begin{abstract}
In this study, the essential oil (EO) of lemongrass (Cymbopogon citratus) or "lemon tea" leaves was studied. The EO was obtained by the steaming $(0.75 \pm 0.05 \%)$ and distillation $(1.5 \pm 0.07 \%)$, assisted by microwaves, methods. The EO had a refractive index of $1.483 \pm 0.001\left(20^{\circ} \mathrm{C}\right)$ and a density of $0.873 \pm 0.005 \mathrm{~g} / \mathrm{mL}\left(27^{\circ} \mathrm{C}\right)$. Color parameters of the oil corroborate the yellow hue observed by the naked eye. The Gas chromatography-Mass spectrometry (GC-MS), Fourier Transform Infrared (FT-IR) Spectrometry, and Nuclear Magnetic Resonance (NMR) techniques permitted to characterize the EO and revealed the chemical structure of the major component: citral (neral and geranial). The phenolic compounds content was $149.2 \pm 6.0 \mathrm{mg}$ Gallic acid equivalents (GAE) per $100 \mathrm{~mL}$ of oil and the antioxidant activity was $44.06 \pm 0.20 \mathrm{mg}$ Trolox (T) per 100 $\mathrm{mL}$ of essential oil.
\end{abstract}

Keywords: essential oil, Cymbopogon citratus, distillation, antioxidant activity, NMR, GC-MS, FT-IR

\section{Introduction}

Essential oils are defined as volatile substances of a complex mixture of chemical components (terpenes, monoterpenes, terpenoids, alcohols, aldehydes, and ketones) which evaporate when contact with air and are biosynthesized by plants (Parikh \& Desai, 2011; Acevedo, Navarro, \& Monroy, 2013). They can be obtained from different parts of plants and are generally recognized as safe (GRAS). Attention is now given to natural antimicrobial substances of plant origin since they could be a rich source of bioactive compounds (Burt, 2004; Silva, Gutierrez, Weisheimer, \& Schapoval, 2008; García et al., 2008; Bakkali et al., 2008) and they might replace synthetic additives. The essential oils of basil (Zivanovic, Chi, \& Draughon, 2005), garlic, cinnamon, lemongrass (Pranoto, Salokhe, \& Rakshit, 2005; Xing et al., 2011; Maqbool et al., 2011; Azarakhsh et al., 2013), oregano (Dos Santos et al., 2012; Vatavali et al., 2013) and rosemary (Ponce, Roura, Del Valle, \& Moreira, 2008) have been added as active chemical compounds in edible coatings.

The scientific name of lemongrass is Cymbopogon citratus. The Cymbopogon word derives from the Greek words "kymbe" (boat) and "pogon" (beard), referring to the arrangement of the spike of the flower. The word citratus derives from the old Latin, meaning lemon-scented leaves (Shah et al., 2011). The common name of Cymbopogon citratus in Mexico is "zacate limón" (lemongrass) or "té limón". It is a perennial tropical grass; is resistant to different temperatures and can grow in warm, semi-warm and temperate climates. It is from 60 to 120 centimeters high, its leaves are green, long and slats and have pleasant aroma and taste. This grass is native to India (Parikh \& Desai, 2011). Because of its pleasant flavor, in Mexico is consumed as infusion in water or milk just because the herbs intake is a custom in the Mexican population (Juárez-Rosete et al., 2013). The essential oil of Cymbopogon citratus has shown to have anti-inflammatory, analgesic and antipyretic properties, (Gbenou et al., 2013) besides having antimicrobial effects (Hammer, Carson, \& Riley, 1999; Pranoto, Salokhe, \& Rakshit, 2005; Adukwu, Allen, \& Phillips, 2012). Tzortzakis \& Economakis (2007) reported that the essential oil of lemongrass inhibited the growth of Botrytis cinerea. Later Raybaudi-Massilia, Rojas-Graü, Mosqueda-Melgar, and Martín-Belloso (2008) reported that the oil of lemongrass could suppress the growth of mesophiles and psychrophiles in fresh-cut apples. 
The aim of this study was to obtain and characterize the essential oil of Cymbopogon citratus.

\section{Materials and Methods}

\subsection{Plant Material}

Fresh Cymbopogon citratus leaves were acquired in the Puebla City Central Market, Puebla, Mexico.

\subsection{Essential Oil Extraction}

Fresh Cymbopogon citratus leaves were dried at room temperature for one week; leaves were extended on trays, turning them three times daily for ventilation, accelerate drying, and preventing the growth of microorganisms. The essential oil of Cymbopogon citratus was obtained by two methods. Hydrodistillation: $50 \mathrm{~g}$ of ground plant material was extracted for about 60 minutes (Baizabal, 2010) using a Clevenger apparatus. Microwave assisted extraction: $50 \mathrm{~g}$ of ground leaves and $200 \mathrm{~mL}$ of distilled water were placed in a $500 \mathrm{~mL}$ spherical flask; the distillation was performed for about $30 \mathrm{~min}$. The distillation apparatus was placed inside of a conventional Daewoo DC (model KOR 6LYB) microwave oven. A power of $600 \mathrm{~W}$ was used. The yield of oil was calculated by the following equation:

Yield $(\%)=($ Oil $(\mathrm{mL})) /($ Plant $(\mathrm{g})) \times 100$

\subsection{Physicochemical Properties}

\subsubsection{Refraction Index}

To measure the refractive index of oil, an Atago ND R5000 refractometer (Osaka, Japan) was used according to the 921.08 AOAC (2000) method.

\subsubsection{Density}

It was assessed according to the 985.19 AOAC (2000) method using a $2 \mathrm{~mL}$ pycnometer.

\subsubsection{Color}

The CIELAB color parameters were measured using a Colorgard 05 colorimeter (Gardner Laboratory, USA) in the transmittance mode. The equipment calibration was performed with the black mosaic and the calibration parameters: $L^{*}=100, a^{*}=0$, and $b^{*}=0$. A cell of quartz and a volume of $3 \mathrm{~mL}$ of oil was used.

\subsection{Gas Chromatography-Mass Spectroscopy}

It was performed using an Agilent Technologies 6850 gas chromatograph (Santa Clara, CA, USA) coupled to an Agilent Technologies 5975 mass selective detector (Santa Clara, CA, USA). An Agilent capillary column (HP-5 ms nonpolar $5 \%$ phenyl methyl polysiloxane) of $30 \mathrm{~m}, 0.25 \mathrm{~mm}$ in diameter and 0.25 microns in thickness was used. Helium, at a flow rate of $1.1 \mathrm{~mL} / \mathrm{min}$, was used as the carrier gas. The oven temperature of the gas chromatograph was maintained at $300{ }^{\circ} \mathrm{C}$. The temperature in the column was started at $60{ }^{\circ} \mathrm{C}$ and maintained for $2 \mathrm{~min}$, then increased, until reaching $250{ }^{\circ} \mathrm{C}$, at a rate of $10{ }^{\circ} \mathrm{C} / \mathrm{min}$. Therefore, the final temperature was maintained for $10 \mathrm{~min}$. One microliter of oil was injected into the column using a split injection of 10:1. The injector temperature was $250^{\circ} \mathrm{C}$ (Conde-Hernández \& Guerrero-Beltrán, 2014). The components were identified by their fragmentation patterns of mass spectra compared with data stored in the National Institute of Standards and Technology Mass Spectral database (NIST-MS, 2010).

\subsection{Fourier Transform Infrared (FT-IR) Spectrometry}

Spectrometry of the EO of Cymbopogon citratus was carried out with a Spectrum One FT-IR Spectrometer, (PerkinElmer ${ }^{\mathbb{B}}$, Waltham, Massachusetts, USA). An EO sample was placed directly on the surface of the ATR top plate at room temperature; measurements were performed in the IR region at $4000-650 \mathrm{~cm}^{-1}$. Four scans were performed at a resolution of $4.00 \mathrm{~cm}^{-1}$ at a scan speed of $0.20 \mathrm{~cm} / \mathrm{s}$. The crystal used was diamond SSNS. An air spectrum was used as reference (Wany et al., 2014).

\subsection{Nuclear Magnetic Resonance (NMR)}

NMR spectroscopic measurements were performed using a Varian Gemini 200 spectrometer (Varian Associates Inc., Palo Alto, CA, USA) (operating at $200 \mathrm{MHz}$ for hydrogen) using deuterated chloroform solution containing tetramethyl silane (TMS) as internal standard (Fortuna et al., 2011).

\subsection{Phenolic Compounds}

The Folin \& Ciocalteu method (Singleton, \& Rossi, 1965) was used for determining phenolic compounds with some modifications. Fifty microliters of EO were diluted with $950 \mu \mathrm{L}$ of ethanol. From this dilution, $500 \mu \mathrm{L}$ were taken and added with $3 \mathrm{~mL}$ of distilled water and $250 \mu \mathrm{L}$ of Folin-Ciocalteu reagent. The reaction was 
stopped adding $750 \mu \mathrm{L}$ of $20 \% \mathrm{Na}_{2} \mathrm{CO}_{3}$. Finally, the solution was brought to $5 \mathrm{~mL}$ with distilled water. The reaction was left in the dark for 2 hours. Samples were filtered through Whatman paper No. 4 before recording absorbances. A blank was prepared with $4 \mathrm{~mL}$ of distilled water, $250 \mu \mathrm{L}$ of Folin-Ciocalteu reagent, and $750 \mu \mathrm{L}$ of $20 \% \mathrm{Na}_{2} \mathrm{CO}_{3}$. The absorbance was recorded at $765 \mathrm{~nm}$ using a UNICO $2800 \mathrm{H}$ UV-visible spectrophotometer (Shanghai, China). Phenolic compounds were expressed in mg equivalent of Gallic acid per $100 \mathrm{~mL}$ of oil. The measurements were performed in triplicate. The phenolics concentration was calculated from a standard curve of Gallic acid $(0-0.0672 \mathrm{mg})$ : Abs $=(15.03 / \mathrm{mg}) *[\mathrm{mg}]+0.0886\left(\mathrm{R}^{2}=0.973\right)$. From a standard solution of Gallic acid $(0.186 \mathrm{mg} / \mathrm{mL})$, nine tubes were prepared to obtain concentrations of 0 to $400 \mu \mathrm{L}$.

\subsection{Antioxidant Capacity $(A C)$}

The method used to determine antioxidant capacity of the essential oil was adapted from Brand-Williams, Cuvelier and Berset (1995) with some modifications. Radical solution: it was prepared dissolving $3.94 \mathrm{mg}$ of DPPH (2,2-Diphenyl-1-picrylhydrazyl) (Sigma-Aldrich, Toluca, Edomex, Mexico) in $100 \mathrm{~mL}$ of ethanol. $A C$ : Fifty $\mu \mathrm{L}$ of EO was mixed with $950 \mu \mathrm{L}$ of ethanol, $2 \mathrm{~mL}$ of DPPH radical solution, made up to $4 \mathrm{~mL}$ with ethanol, and thoroughly mixed. The mixture was left to react in the dark for 30 minutes. The absorbance of samples $\left(A_{s}\right)$ was recorded at $517 \mathrm{~nm}$ in a UNICO ${ }^{\circledR} 2800 \mathrm{H}$ UV-visible spectrophotometer (Shanghai, China). A blank $\left(A_{b}\right)$ was prepared using the same procedure substituting only the sample for ethanol. The percentage of inhibition $(I)$ was calculated as follow:

$I=\left(\left(A_{b}-A_{s}\right) / A_{b}\right) * 100$

The antioxidant capacity $(\mathrm{mg} \mathrm{T} / 100 \mathrm{~mL}$ of EO) was calculated from a standard curve of Trolox $(0-0.028 \mathrm{mg}): I=$ $(2699.2 / \mathrm{mg}) *[\mathrm{mg}]-4.3749\left(\mathrm{R}^{2}=0.989\right)$. To prepare the calibration curve a standard solution of Trolox $(( \pm)$-6-Hydroxy-2,5,7,8-tetramethylchromane-2-carboxylic acid, $97 \%)$ was prepared $(0.35 \mathrm{mg} / \mathrm{mL})$ in ethanol. Eight tubes were used to obtain concentrations in the range 0 to $0.028 \mathrm{mg}$ of Trolox.

\subsection{Statistic Analysis}

An analysis of variance and Tukey test were performed to state differences between means using the Minitab 17 software (LEAD Technologies Inc., NJ). A P value of 0.05 was considered statistically significant.

\section{Results and Discussion}

\subsection{Essential Oil Yield}

Yields of $0.752 \pm 0.05$ and $1.5 \pm 0.07 \%(\mathrm{~V} / \mathrm{W})$ of EO were obtained by the steam and microwave assisted distillation methods, respectively. Differences $(\mathrm{p}<0.05)$ within means of yields were observed. Very probably the core of ground plant placed in the spherical flask was efficiently heated due to microwaves. As observed in other works, when using a simple distillation procedure, sometimes the steam do not reach the center of the ground plant; therefore, the yield of the oil extraction is not optimized. The moisture content of the dried $C$. citratus was $9.14 \pm 0.70 \%$.

\subsection{Physical Properties}

The values of refractive index, color, and density are shown in Table 1 . These values are close to those reported by Tovar et al. (2011) $(\rho=0.885 \mathrm{~g} / \mathrm{mL}$; IR = 1.482), Paviani, Pergher, and Dariva (2006) $(\rho=0.848 \mathrm{~g} / \mathrm{mL})$, Essien, Essien, Ita, \& Ebong (2008) $(\rho=0.888 \mathrm{~g} / \mathrm{mL} ; \mathrm{IR}=1.477)$, Ibrahim, Ibo and Adejare (2010) $(\rho=0.866$ $\mathrm{g} / \mathrm{mL} ; \mathrm{IR}=1.472)$, and Monteiro et al. (2011) $(\rho=0.949 \mathrm{~g} / \mathrm{mL} ; \mathrm{IR}=1.332)$ who reported similar refractive index and specific gravity values for essential oils of lemongrass, lemongrass, citron (Citrus medica L.), ginger, and allspice (Pimenta dioica), respectively, obtained by hydrodistillation. Color parameters indicate a yellow hue (68.81 \pm 0.36 ) which was observed in the EO. Tovar et al. (2011) reported high values for $L^{*}(98.59$ to 101.63$)$ but similar values for $a^{*}(-2.45)$, and $b^{*}(6.28)$ color parameters for the Cymbopogon citratus EO. 
Table 1. Refractive index, density, and color parameters of dried C. citratus EO obtained by distillation assisted by microwaves

\begin{tabular}{lll}
\hline Characteristic & & Value \\
\hline Refraction index $\left(20^{\circ} \mathrm{C}\right)$ & & $1.483 \pm 0.001$ \\
Density $(\mathrm{g} / \mathrm{mL})\left(27^{\circ} \mathrm{C}\right)$ & & $0.873 \pm 0.005$ \\
Color parameters & $L^{*}$ & $97.04 \pm 0.25$ \\
& $a^{*}$ & $-2.44 \pm 0.04$ \\
& $b^{*}$ & $6.29 \pm 0.12$ \\
\hline
\end{tabular}

\subsection{Chemical Compounds by GC-MS}

Tables 2 and 3 list the main components of the EO of C. citratus revealed by the GC-MS technique.

Table 2. Chemical compounds of essential oil of dried C. citratus obtained by steam distillation

\begin{tabular}{ll}
\hline Chemical & Area (\%) \\
\hline Cis-linalool oxide & 0.7 \\
Linalool & 0.64 \\
2-hydroxy-1, 1, 10-trimethyl-6,9-decalin epidioxi & 8.09 \\
Oxirane methanol, 3-methil-3-(4-methyl-3-pentenyl) & 28.4 \\
Dihydronopol & 2.52 \\
Neral & 19.35 \\
Geranial & 15.97 \\
Geranic acid & 5.76 \\
Neric acid & 9.15 \\
2-tridecanone & 1.21 \\
7-Methyl-z-tetradecen-1-ol- acetate & 2.37 \\
1-allyl-2-hydroxy-6-methyl-cyclohexanecarboxylic acid & 1.1 \\
9-methyl-z10-tetradecen-1-ol-acetate & 4 \\
Cholestan-3-ol, 2-methylene (3 $\beta, 5 \alpha)$ & 0.3 \\
Ethyl-linoleate & 0.43 \\
\hline
\end{tabular}

Table 3. Chemical compounds of essential oil of dried C. citratus obtained by distillation assisted by microwaves

\begin{tabular}{ll}
\hline Chemical & Area (\%) \\
\hline 3-Methyl-2-butenal & 0.16 \\
Nerol & 1 \\
Limonene & 0.46 \\
Citronellal & 0.21 \\
2-cyclohexen-1-one & 0.33 \\
Cis-linalool oxide & 0.4 \\
Linalool & 0.86 \\
Neral & 29 \\
Geranial & 22.63 \\
Methyl acetate & 2.56 \\
Oxirane carboxaldehyde, 3-methyl-3-(4-methyl-3-pentenyl) & 25.29 \\
Cis-pulegone oxide & 3.25 \\
Neric acid & 9.19 \\
Carotol & 0.88 \\
7-methyl-z-tetradecen-1-ol-acetate & 0.25 \\
\hline
\end{tabular}


The predominant component of the essential oil of C. citratus obtained by the two distillation methods of extraction was citral (mixture of geranial and neral aldehydes) (Figure 1). These results agree with those reported by Mahanta et al. (2007) and Negrelle and Gomes (2007). Adukwu, Allen, and Phillips (2012) and Andrade et al. (2012) informed that citral was the main component in C. flexuosusu and C. nardus, respectively. The highest percentage $(51.63 \%)$ of citral in the EO obtained by the microwave assisted distillation method is close to that reported by León-Anzueto et al. (2011) (59.7 to 64.0\%) in C. citratus (DC.) Stapf. Chanthai, Prachakoll, Ruangviriyachai, and Luthria (2012) reported that the plant has a content of citral of 65 to $80 \%$. Mohamed Hanaa, Sallam, El-Leithy, and Aly (2012) reported concentrations of geranial (31.53\%, 39.86\% and 37.24\%), neral $(30.08 \%, 34.52 \%$ and $31.28 \%)$ and myrcene $(16.61 \%, 14.49 \%$ and $15.42 \%)$ in essential oils extracted from leaves of Cymbopogon citratus, dried in the sun, in the shade, and in oven, respectively. The differences in type of components reported by other researchers is probably due to the climatic conditions where the plant was grown. The quality of Cymbopogon citratus is determined by the content of citral. It has been observed that citral has an inhibitory effect on bacteria and fungi (Adinarayana et al., 2012; Marques et al., 2013).<smiles>CC(C)=CCCC(C)=CC=O</smiles>

Geranial, $\alpha$-citral<smiles>CC(=CC=O)CCC(C)C</smiles>

Neral, $\beta$-citral

Figure 1. Chemical structures of geranial and neral

\subsection{Infrared Spectrum}

As mentioned above, the main component of the C. citratus EO is citral. In the IR spectrum (Figure 2) of EO of C. citratus, the functional groups of citral were observed. In the vibrations at $2968 \mathrm{~cm}^{-1}$, a predominant asymmetric stretching of $-\mathrm{CH}_{3}$ is observed corresponding to an alkyl saturated aliphatic group and at 2915 and $2857 \mathrm{~cm}^{-1}$, symmetric and asymmetric stretching of $-\mathrm{CH}_{2}$ are observed. The intense band observed at $1671 \mathrm{~cm}^{-1}$ is due to vibrations of $\mathrm{C}=\mathrm{C}$ ( cis and trans), confirming the presence of conjugated double bonds $(\mathrm{C}=\mathrm{C}-\mathrm{CHO})$ in citral which are common in acyclic monoterpenes. The peak at $1632 \mathrm{~cm}^{-1}$ indicates stretching of $\mathrm{C}=\mathrm{O}$ of the aldehyde group. At the $1442 \mathrm{~cm}^{-1}$ peak, bending of the $-\mathrm{CH}_{2}$ group is observed. At $1377 \mathrm{~cm}^{-1}$ bending of $-\mathrm{CH}_{3}$ group is observed. From 1194 to $1120 \mathrm{~cm}^{-1}$, stretching of $-\mathrm{C}-\mathrm{O}$ and vibrations of the -CH skeleton are observed. At $841 \mathrm{~cm}^{-1}$, substitution in 1,3 and 1,4 are observed. Similar peaks were reported by Wany et al. (2014) for geranial from other species of Cymbopogon winterianus (citronella grass).

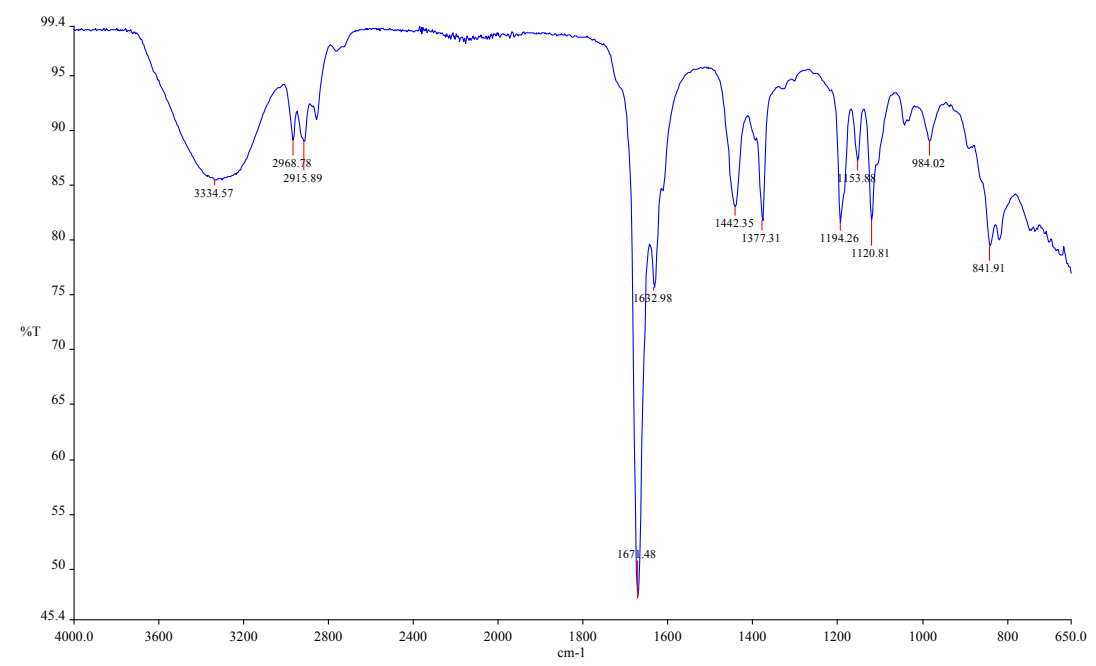

Figure 2. Infrared spectrum of Cymbopogon citratus essential oil 
The IR spectrum of $C$. citratus EO is consistent with data obtained from gas chromatography coupled to mass spectroscopy, IR shows principally the citral spectrum (Mahanta et al., 2007; Marques et al., 2013) which is the main component in the mixture of chemicals in this oil. In addition, the IR spectrum shows absorption at 3334 $\mathrm{cm}^{-1}$, characteristic of the $-\mathrm{OH}$ group which is also in agreement with results of the GC-MS analysis where the presence of nerol and other alcohols in small proportions were observed.

\subsection{Nuclear Magnetic Resonance (NMR)}

The NMR analysis allowed the characterization and structural elucidation of the main component in the essential oil of $C$. citratus. The NMR spectra of hydrogen $(1 \mathrm{H})$ (Figure 3) and carbon-13 (C 13) (Figure 4) clearly show that the EO of C. citratus is composed of citral (Restrepo, Vinasco, Jaramillo, \& Colmenares, 2009), where the two typical signals of the group aldehyde correspond to geranial and neral in proportions of 61 and $39 \%$, respectively.

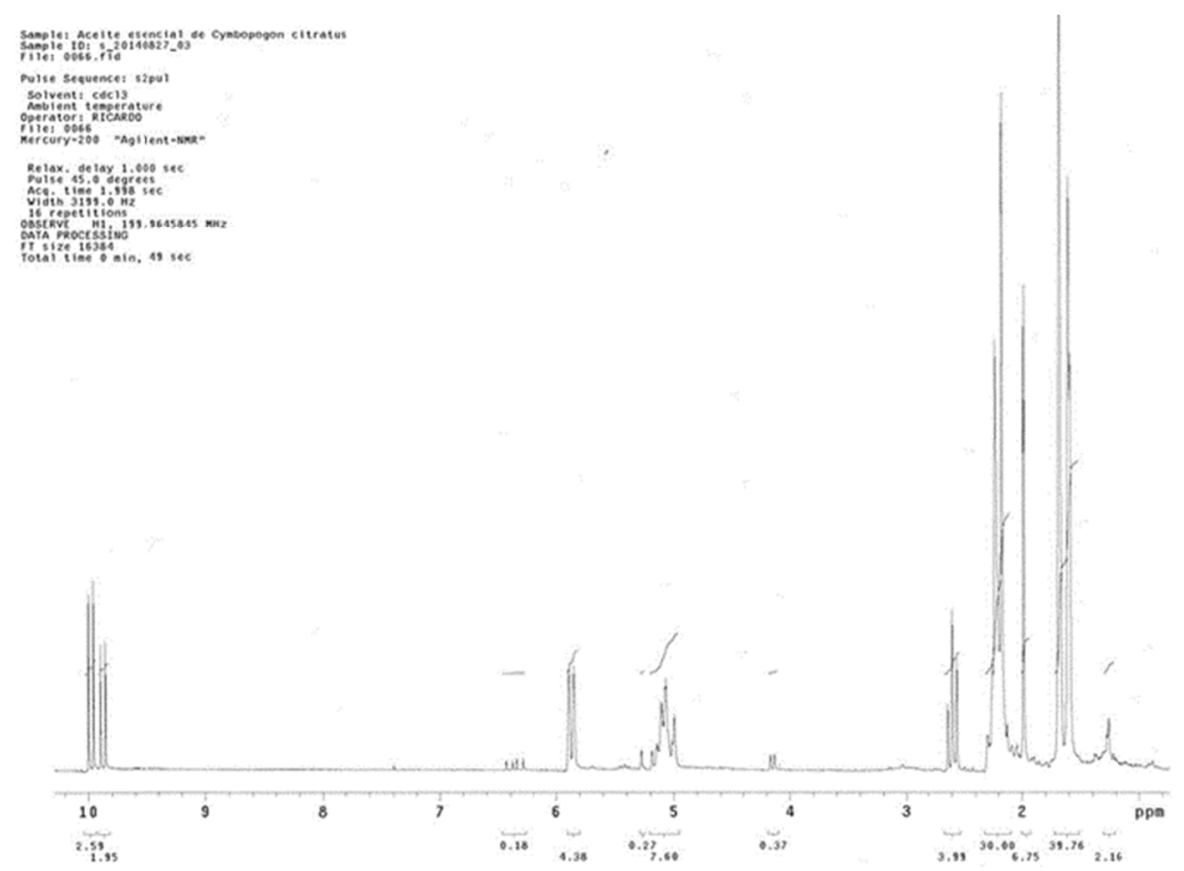

Figure 3. 1 H NMR spectrum of Cymbopogon citratus essential oil

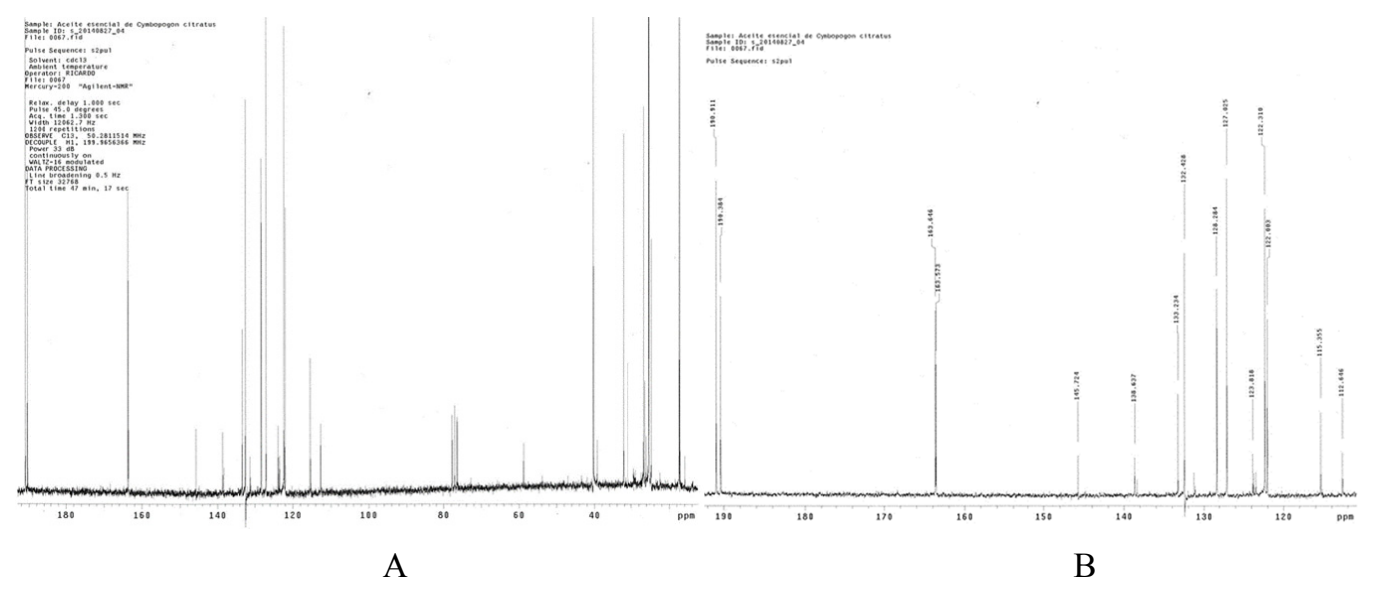




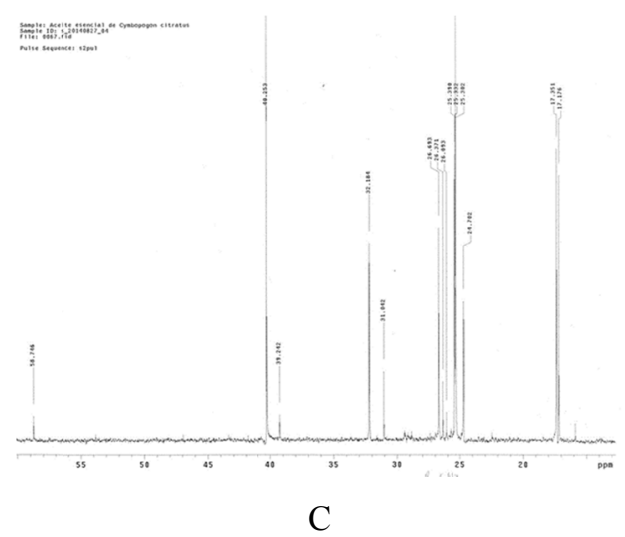

Figure 4. 13 C NMR spectrum of Cymbopogon citratus essential oil

\subsection{Phenolic Compounds}

Fruits and vegetables containing phenolic compounds may have high antioxidant activity, which means that they could have positive effects on the preservation of foods quality and human health (Becker, Nissen, \& Skibsted, 2004). Some studies have shown that phenolic compounds having antioxidant activity may retard aging, prevent degenerative diseases such as cancer, cardiovascular disorders, and brain dysfunctions (Ames, Shigenaga, \& Hagen, 1993). In this study, a phenolic content of $149.2 \pm 6.0 \mathrm{mg}$ GAE per $100 \mathrm{~mL}$ of oil (obtained by distillation assisted by microwaves) was obtained. Koh, Mohd, Mokhtar, \& Iqbal (2012) reported a phenolic content of $30.74 \pm 1.13 \mathrm{mg}$ GAE per g of sample in ethanol extracts of Cymbopogon citratus. Mirghani, Liyana, and Parveen (2012) reported $184.69 \mathrm{mg}$ of GAE per $100 \mathrm{~mL}$ of EO of Cymbopogon citratus lives. Several factors can affect the content of phenolic compounds in plants: preparation (drying time, temperature, among others) and growing conditions of the plant as well as the extracting method and the technique of analysis (Moraes-de-Souza et al., 2008).

\subsection{Antioxidant Capacity}

The essential oil of $C$. citratus had an antioxidant capacity of $44.06 \pm 0.20 \mathrm{mg}$ Trolox per $100 \mathrm{~mL}$ of essential oil (obtained by distillation assisted by microwaves), equivalent to $55.57 \%$ of inhibition. Selim (2011) reported values of 40.63 to $63.75 \%$ inhibition for Cymbopogon proximus (Stapf). Mirghani, Liyana, and Parveen (2012) reported higher values of inhibition $(78.89 \%)$ when diluting the EO at 1:2 oil:methanol proportion. The differences in the antioxidant capacity values, reported by different researchers, can be attributed to factors such as climate, soil composition, and season as well as part, age and stage of growing of the plant (Angioni et al., 2006) in addition to the EO or extract concentration (Mirghani, Liyana, \& Parveen, 2012). The antioxidant activity of the $\mathrm{EO}$ of $C$. citratus could be of great interest in the food industry to be used as a natural additive for flavoring.

\section{Conclusions}

The distillation, assisted by microwaves, was the best method for extracting the EO. The physicochemical properties of the EO of C. citratus were determined. The EO of C. citratus had high citral (a mixture of geranial and neral aldehydes) concentration which was corroborated by different instrumental techniques (GC-MS, FT-IR, and NMR). The EO showed high phenolics content (149.20 mg GAE per $100 \mathrm{~mL}$ ) and antioxidant capacity (44.06 mg Trolox per $100 \mathrm{~mL}$ of essential oil).

\section{Acknowledgments}

María del Carmen Vázquez-Briones thanks to PROMEP (Program for the Educational Professional Improvement) for the scholarship granted to complete her doctoral studies.

\section{References}

AOAC. (2000). Official Methods of Analysis of the AOAC International. (2000). 7th Edition, Volume II, Gaithersburg, Maryland, USA. Chapter 41, pp. 2-4.

Acevedo, D., Navarro, M., \& Monroy, L. (2013). Composición química del aceite esencial de hojas de orégano $\begin{array}{lllll}\text { (Origanum vulgare). } & \text { Información } & \text { Tecnológica, } & \text { 24(4), }\end{array}$ http://dx.doi.org/10.4067/S0718-07642013000400005 
Adinarayana, G., Rahul, G., Kiran, R. S., Syamsundar, K. V., \& Rajeswara, B. R. (2012). Evaluation of antimicrobial potential of field distilled and water-soluble essential oils of Cymbopogon flexuosus. Journal of Pharmacognosy, 3(2), 142-146.

Adukwu, E. C., Allen, S. C. H., \& Phillips, C. A. (2012). The anti-biofilm activity of lemongrass (Cymbopogon flexuosus) and grapefruit (Citrus paradisi) essential oils against five strains of Staphylococcus aureus. Journal of Applied Microbiology, 113, 1217-1227. http://dx.doi.org/10.1111/j.1365-2672.2012.05418.x

Ames, B. N., Shigenaga, M. K., \& Hagen, T. M. (1993). Oxidants, antioxidants, and the degenerative diseases of aging. Proceedings of the National Academy of Sciences of the United States of America, 90, 7915-7922. http://dx.doi.org/10.1073/pnas.90.17.7915

Andrade, M. A., Cardoso, M. G., Batista, L. R., Mallet, A. C. T., \& Machado, S. M. F. (2012). Óleos essenciais de Cymbopogon nardus, Cinnamomum zeylanicum e Zingiber officinale: composição, actividades antioxidante e antibacteriana. Revista Ciência Agronômica, 43(2), 399-408. http://dx.doi.org/10.1590/S1806-66902012000200025

Angioni, A., Barra, A., Coroneo, V., Dessi, S., \& Cabras, P. (2006). Chemical composition, seasonal variability, and antifungal activity of Lavandula stoechas L. ssp. stoechas essential oils from stem/leaves and flowers. Journal of Agricultural and Food Chemistry, 54, 4364-4370. http://dx.doi.org/10.1021/jf0603329

Azarakhsh, N., Osman, A., Ghazali, H. M., Tan, C. P., \& Mohd Adzahan, N. (2013). Lemon grass essential oil incorporated into alginate-based edible coating for shelf-life extension and quality retention of fresh-cut $\begin{array}{llllll}\text { pineapple. Postharvest Biology } & \text { and }\end{array}$ http://dx.doi.org/10.1016/j.postharvbio.2013.09.004

Baizabal, C. R. H. (2010). Evaluación de la capacidad antioxidante y antimicrobiana del aceite esencial y del polvo de romero (Rosmarinus officinalis $\mathrm{L}$.) en queso fresco de vaca. Bachelor Thesis. Universidad de las Américas Puebla. Puebla, Mexico.

Bakkali, F., Averbeck, S., Averbeck, D., \& Idaomar, M. (2008). Biological effects of essential oils - a review. Food and Chemical Toxicology, 46, 446-475. http://dx.doi.org/10.1016/j.fct.2007.09.106

Becker, E. M., Nissen, L. R., \& Skibsted, L. H. (2004). Antioxidant evaluation protocols: food quality or health effects. European Food Research and Technology, 219, 561-571. http://dx.doi.org/10.1007/s00217-004-1012-4

Brand-Williams, W., Cuvelier, M. E., \& Berset, C. (1995). Use of free radical method to evaluate antioxidant $\begin{array}{llll}\text { activity. } \quad \text { LWT-Food } & \text { Science }\end{array}$ http://dx.doi.org/10.1016/S0023-6438(95)80008-5

Burt, S. (2004). Essential oils: their antibacterial properties and potential applications in foods a review. $\begin{array}{lllll}\text { International Journal of } & \text { Food } 223-253 .\end{array}$ http://dx.doi.org/10.1016/j.ijfoodmicro.2004.03.022

Chanthai, S., Prachakoll, S., Ruangviriyachai, C., \& Luthria, D. L. (2012). Influence of extraction methodologies on the analysis of five major volatile aromatic compounds of citronella grass (Cymbopogon nardus) and lemongrass (Cymbopogon citratus) grown in Thailand. Journal of AOAC International, 95(3), 763-772. http://dx.doi.org/10.5740/jaoacint.11-335

Conde-Hernández, L. A. \& Guerrero-Beltrán, J. Á. (2014). Total phenolics and antioxidant activity of Piper auritum and Porophyllum ruderale. Food Chemistry 142, 455-460. http://dx.doi.org/10.1016/j.foodchem.2013.07.078

Dos Santos, N. S. T., Athayde, A. J. A., De Oliveira, C. E. V., Veríssimo, C., De Melo, S., Sousa, R., ... De Souza, E. L. (2012). Efficacy of the application of a coating composed of chitosan and Origanum vulgare L. essential oil to control Rhizopus stolonifer and Aspergillus niger in grapes (Vitis labrusca L.). Food Microbiology, 32, 345-353. http://dx.doi.org/10.1016/j.fm.2012.07.014

Essien, E., Essien, J., Ita, B., \& Ebong, G. (2008). Physicochemical properties and fungitoxicity of the essential oil of Citrus medical L. against groundnut storage fungi. Turkish Journal of Botany, 32(2), 161-164.

Fortuna, A. M., Juarez, Z. N., Bach, H., Nematallah, A., Av-Gay, Y., Sánchez-Arreola, E., ... Hernández, L. R. (2011). Antimicrobial activities of sesquiterpene lactones and inositol derivatives from Hymenoxys robusta. Phytochemestry, 72, 2413-2418. http://dx.doi.org/10.1016/j.phytochem.2011.09.001

García, R., Alves, E. S. S., Santos, M. P., Aquije, G. M. F. V., Fernández, A. A. R., Santos, R. B., ... Fernández, P. 
M. V. (2008). Antimicrobial activity and potential use of monoterpenes as tropical fruits preservatives. Brazilian Journal of Microbiology, 39, 163-168. http://dx.doi.org/10.1590/S1517-83822008000100032

Hammer, K. A., Carson, C. F., \& Riley, T. V. (1999). Antimicrobial activity of essential oils and other plant $\begin{array}{lllll}\text { extracts. Journal of } & \text { Applied }\end{array}$ http://dx.doi.org/10.1046/j.1365-2672.1999.00780.x

Ibrahim, T. A., Ibo, D., \& Adejare, A. R. (2010). Comparative phytochemical properties of crude ethanolic extracts and physicochemical characteristics of essential oils of Myristical fragrans (nutmeg) seeds and Zingiber officinate (ginger) roots. Electronic Journal of Environmental, Agricultural and Food Chemistry, 9(6), 1110-1116.

Juárez-Rosete, C. R., Aguilar-Castillo, J. A., Juárez-Rosete, M, E., Bugarín-Montoya, R., Juárez-López, P., \& Cruz, C. E. (2013). Hierbas aromáticas y medicinales en México: tradición e innovación. Revista Bio Ciencias, 2(3), 119-129.

Koh, P. H., Mohd, R. A., Mokhtar, \& Iqbal. M. (2012). Antioxidant potential of Cymbopogon citratus extract: alleviation of carbon tetrachloride-induced hepatic oxidative stress and toxicity. Human and Experimental Toxicology, 31(1) 81-91. http://dx.doi.org/10.1177/0960327111407226

León-Anzueto, E., Abud-Archila, M., Dendooven, L., Ventura-Canseco, L. M. C., \& Gutiérrez-Miceli, F. A. (2011). Effect of vermicompost, worm-bed leachate and arbuscular mycorrizal fungi on lemongrass (Cymbopogon citratus (DC) Stapf.) growth and composition of its essential oil. Electronic Journal of Biotechnology, 14(6), 1-11.

Mahanta, J. J., Chutia, M. Bordoloi, M., Pathak, M. G. Adhikary, R. K., \& Sarma, T. C. (2007). Cymbopogon citratus L. essential oil as a potential antifungal agent against key weed moulds of Pleurotus spp. Spawns. Flavour and Fragrance Journal, 22, 525-530. http://dx.doi.org/10.1002/ffj.1835

Maqbool, M., Ali, A., Alderson, P. G., Mohamed, M. T. M., Siddiqui, Y., \& Zahid, N. (2011). Postharvest application of gum Arabic and essential oils for controlling anthracnose and quality of banana and papaya during cold storage. Postharvest Biology and Technology, 62, 71-76. http://dx.doi.org/10.1016/j.postharvbio.2011.04.002

Marques. A. M., Lima, C. H. P., Alviano, D. S., Alviano, C. S., Esteves, R. L., \& Kaplan, M. A. C. (2013). Traditional use, chemical composition and antimicrobial activity of Pectis brevipedunculata essential oil: A correlated lemongrass species in Brazil. Journal of Food and Agriculture, 25(10), 798-808.

Mirghani, M. E. S., Liyana, Y., \& Parveen, J. (2012). Bioactivity analysis of lemongrass (Cymbopogan citratus) essential oil. International Food Research Journal, 19(2), 569-575.

Mohamed Hanaa, A. R. Sallam, Y. I., El-Leithy, A. S., \& Aly, S. E. (2012). Lemongrass (Cymbopogon citratus) essential oil as affected by drying methods. Annals of Agricultural Science, 57(2), 113-116. http://dx.doi.org/10.1016/j.aoas.2012.08.004

Monteiro, O. O., Souza, A. A., Soledade, L. L., Queiroz, N. N., Mouchrek Filho, V. V., \& Vasconcelos, A. A. (2011). Chemical evaluation and thermal analysis of the essential oil from the fruits of the vegetable species Pimenta dioica Lindl. Journal of Thermal Analysis \& Calorimetry, 106(2), 595-600. http://dx.doi.org/10.1007/s10973-011-1438-4

Moraes-de-Souza, R. A., Oldoni, T. L. C., Regitano-d'Arce, M. A. B., \& Alencar, S. M. (2008). Actividad antioxidante y compuestos fenólicos en infusiones herbarias consumidas en Brasil. Ciencia y Tecnología Alimentaria (Brasil), 6(1), 41-47. http://dx.doi.org/10.1080/11358120809487626

National Institute of Standards and Technology (NIST). (2010). Automated mass spectral library with search program (Data version: NIST11, Version 2.0).

Negrelle, R. R. B., \& Gomes, E. C. (2007). Cymbopogon citratus (DC.) Stapf: chemical composition and biological activities. Revista Brasileira de Plantas Medicinais Botucatu (Brasil), 9(1), 80-92.

Parikh, J. K., \& Desai, M. A. (2011). Hydrodistillation of essential oil from Cymbopogon flexuosus. International Journal of Food Engineering, 7(1), 1-9. http://dx.doi.org/10.2202/1556-3758.2067

Paviani, L., Pergher, S. B. C., \& Dariva, C. (2006). Application of molecular sieves in the fractionation of lemongrass oil from high-pressure carbon dioxide extraction. Brazilian Journal of Chemical Engineering, 23, 219-225. http://dx.doi.org/10.1590/S0104-66322006000200009

Ponce, A. G., Roura, S. I., Del Valle, C. E., \& Moreira, M. R. (2008). Antimicrobial and antioxidant activities of 
edible coating enriched with natural plant extracts: in vitro and in vivo studies. Postharvest and Biology Technology, 49, 294-300. http://dx.doi.org/10.1016/j.postharvbio.2008.02.013

Pranoto, Y., Salokhe, V. M., \& Rakshit, S. K. (2005). Physical and antimicrobial properties of alginate-based edible film incorporated with garlic oil. Food Research International, 38, 267-272. http://dx.doi.org/10.1016/j.foodres.2004.04.009

Raybaudi-Massilia, R. M., Rojas-Graü, M. A., Mosqueda-Melgar, J., \& Martín-Belloso, O. (2008). Comparative study on essential oils incorporated into an alginate-based edible coating to assure the safety and quality of fresh-cut Fuji apples. Journal of Food Protection, 71, 1150-1161.

Restrepo, J., Vinasco, L. E., Jaramillo, L. P., \& Colmenares, A. J. (2009). Encapsulamiento de los aceites esenciales de citral (Cymbopogon citratus) en $\beta$-ciclodextrinas usando $\mathrm{CO}_{2}$ supercrítico. Ingeniería y Competitividad, 11(2), 9-19.

Selim, S. A. (2011). Chemical composition, antioxidant and antimicrobial activity of the essential oil and methanol extract of the Egyptian lemongrass Cymbopogon proximus Stapf. Grasas y aceites, 62(1), 55-61. http://dx.doi.org/10.3989/gya.033810

Shah, G., Shri, R., Panchal, V., Sharma, N., Singh, B., \& Mann, A. S. (2011). Scientific basis for the therapeutic use of Cymbopogon citratus, Stapf (Lemon grass). Journal of Advanced Pharmaceutical Technology and Research, 2, 3-8. http://dx.doi.org/10.4103/2231-4040.79796

Singleton, V. L., \& Rossi, J. A. (1965). Colorimetry of total phenolics with phosphomolybdic-phosphotungstic acid reagents. American Journal of Enology and Viticulture, 16(3), 144-158.

Silva, C. B., Gutierrez, S. S., Weisheimer, V., \& Schapoval, E. S. S. (2008). Antifungal activity of the lemongrass oil and citral against Candida spp. Brazilian Journal of Infectious Diseases, 2(1), 63-66.

Tovar, L. P., Pinto, G. M. F., Wolf-Maciel, M. R., Batistella, C. B., \& Maciel-Filho, R. (2011). Short-path-distillation process of lemongrass essential oil: physicochemical characterization and assessment quality of the distillate and the residue products. Industrial \& Engineering Chemistry Research, 50(13), 8185-8194. http://dx.doi.org/10.1021/ie101503n

Tzortzakis, N. G., \& Economakis, C. D. (2007). Antifungal activity of lemongrass (Cymbopogon citratus L.) essential oil against key postharvest pathogens. Innovative Food Science and Emerging Technology, 8, 253-258. http://dx.doi.org/10.1016/j.ifset.2007.01.002

Vatavali, K., Karakosta, L., Nathanailides, C., Georgantelis, D., \& Kontominas, M. G. (2013). Combined effect of chitosan and oregano essential oil dip on the microbiological, chemical, and sensory attributes of red porgy (Pagrus pagrus) stored in ice. Food and Bioprocess Technology, 6, 3510-352. http://dx.doi.org/10.1007/s11947-012-1034-z

Wany, A., Kumar, A., Nallapeta, S., Jha, S., Nigam, V. K., \& Pandey, D. M. (2014). Extraction and characterization of essential oil components based on geraniol and citronellol from Java citronella (Cymbopogon winterianus Jowitt). Journal of Plant Growth Regulation, 73, 133-145. http://dx.doi.org/10.1007/s10725-013-9875-7

Xing, Y., Li, X., Xu, Q., Yun, J., Lu, Y., \& Tang, Y. (2011). Effects of chitosan coating enriched with cinnamon oil on qualitative properties of sweet pepper (Capsicum annuum L.). Food Chemistry, 124, 1443-1450. http://dx.doi.org/10.1016/j.foodchem.2010.07.105

Zivanovic, S., Chi, S., \& Draughon, A. F. (2005). Antimicrobial activity of chitosan films enriched with essential oils. Journal of Food Science, 70, M45-M51. http://dx.doi.org/10.1111/j.1365-2621.2005.tb09045.x

\section{Copyrights}

Copyright for this article is retained by the author(s), with first publication rights granted to the journal.

This is an open-access article distributed under the terms and conditions of the Creative Commons Attribution license (http://creativecommons.org/licenses/by/3.0/). 